\title{
SUA DARA SEBAGAI ALTERNATIF MEDIA PEMBELAJARAN SEJARAH MAHASISWA PROGRAM STUDI PENDIDIKAN SEJARAH IKIP PGRI MADIUN
}

\author{
Novi Triana Habsari*
}

\begin{abstract}
Abstrak
Pembelajaran sejarah hendaknya dapat dilaksanakan dengan kegiatan yang inovatif, kreatif, dan menarik sehingga mampu memotivasi peserta didik untuk lebih mencintai sejarah. Selama ini paradigma yang berkembang hanyalah terkesan menyudutkan sejarah, bagaimana tidak, sejarah di klaim merupakan mata pelajaran yang membosankan. Pendidik dalam menyampaikan materipun tidak jarang yang hanya ceramah tanpa dibubuhi fakta. Kurangnya upaya untuk menerapkan metode pengajaran dan juga kreativitas dalam menciptakan media pembelajaran pun semakin memperparah citra sejarah. Melihat berbagai permasalahan yang ada, penulis memberikan salah satu alternatif berupa media Sua Dara. Media ini merupakan visualisasi dari benda-benda cagar budaya yang ada di sekitar Madiun. Melalui pembuatan media ini diharapkan mahasiswa akan termotivasi dantertarik untuk mempelajari sejarah lebih luas lagi. Selain itu adanya medi Sua Dara ini diharapkan mampu memberikan gambaran kepada mahasiswa bahwa belajar sejarah itu menyenangkan terlebih kita menjadi tahu ternyata di sekitar tempat tinggal banyak terdapat benda cagar budaya. Sehingga dengan demikian kesan buruk mahasiswa ataupun peserta didik terhadap sejarah menjadi hilang dan tergantikan oleh image bahwapembelajaran sejarah itu menarik.
\end{abstract}

\section{Kata Kunci: Video, Benda Cagar Budaya, Media Pembelajaran Sejarah}

\section{Pendahuluan}

Pendidikan merupakan usaha untuk mencerdaskan kehidupan bangsa dan dilakukan oleh orang-orang yang telah diserahi tanggung jawab dalam rangka mengelola lembaga pendidikan mulai dari lingkungan sekolah sampai perguruan tinggi. Adanya pengelolaan tersebut dimaksudkan agar sistematika kerjanya dalam mewujudkan output sumber daya manusia dapat menunjukkan pada kualitas dan harapan sesuai cita-cita bangsa. esensi dari kualitas ini dapat diasumsikan bahwa terjadinya suatu upaya pengubahan perilaku semestinya sebagai hasil dari proses belajar. keterkaitan dari esensi itu adalah bagaimana pendidikan itu sendiri secara substansial memungkinkan untuk membentuk kepribadian peserta didik yang unggul, berkarakter dan mampu mengembangkan wawasan keilmuannya. desain pendidikan dalam bingkai pembentukan kepribadian perlu mendapatkan porsi yang maksimal.

Oleh sebab itu, tidak heran jika banyak penyedia pendidikan terus mencoba untuk melakukan pengkonstruksian dalam pusaran perubahan perilaku (behaviorisme), pemahaman konsep (kognitivisme), eksistensi pengalaman seseorang (humanistic), kebutuhan akan informasi (sibernitik), dan kondisi psikologis seseorang (motivasi) (Ahmad Baedowi, 2012: 101). Apa yang tercantum dari 
konsep demikian itu dapat terealisasi apabila terbangun suatu relasi yang seimbang antara penyedia pendidikan maupun pendidik itu sendiri. pendidikan tidak akan bisa lepas dengan proses pembelajaran. dua komponen tersebut saling melakukan relasi untuk membentuk konstruksi sumber daya manusia ke arah yang berkualitas.

Apabila berbicara mengenai masalah tersebut, secara implisit maka keberhasilan penyelenggaran pendidikan juga akan tersinergi dengan kemampuan suatu lembaga terhadap pengelolaan pendidik dalam proses pembelajaran. Artinya bahwa kemampuan pendidik dalam peranannya mengelola proses pembelajaran agar keberhasilan belajar yang sesuai dengan standar capaian pendidikan perlu didorong secara berkala. ketercapaian tersebut minimal dapat mengkonstruk kepribadian yang berkarakter humanistic. pendidik baik dari tingkatan guru, tutor, instruktur maupun dosen mempunyai peran penting dalam proses transformasi pembelajaran. transformasi itu dapat melalui penguasaan strategi, materi, atau media. Apalagi bila dicermati bersama bahwa sekarang ini pendidikan telah memasuki abad ke 21, dan ditandai dengan orientasi perubahanperubahan yang bersifat multidimensional yang menuntut untuk memahami dan menanggapi berbagai kecenderungan agar, sebagai pendidik dapat mempersiapkan diri untuk tugas-tugas pembimbingan akan kehidupan masa depan peserta didik kita (Soebijantoro dalam Agastya, 2011: 22).

Dalam hal ini, Dosen yang merupakan salah satu dari unsur pendidik dengan tanggung jawab besar terhadap transformasi pengetahuan ketika proses pembelajaran kepada mahasiswa berlangsung. Mengingat pada era sekarang ini, keberadaan inovasi-inovasi pembelajaran baru baik berupa model, strategi, maupun media menjadi tuntutan dan kebutuhan utama bagi seorang dosen. esensinya adalah apabila dosen mampu mengembangkan inovasi pembelajarannya tentu mahasiswa dapat membangun dengan mudah materi perkuliahan. Sebaliknya apabila seorang dosen tidak mampu untuk mencoba berimprovisasi dalam upaya pengembangan inovasi model, metode bahkan bahan ajar maka motivasi mahasiswa akan rendah.

Apabila itu terjadi maka akan dapat menjadi persoalan pada beberapa kajian bidang ilmu pelajaran tertentu khususnya Sejarah. pada umumnya pengalaman pembelajaran mata kuliah bidang Sejarah di perguruan tinggi berkecenderungan menggunakan pendekatan konvensional. kondisi seperti ini menimbulkan anggapan mahasiswa secara sisi psikologis bahwa pembelajaran sejarah kurang menarik atau membosankan. persoalan ini membuat mahasiswa sulit memahami materi yang disampaikan. hal ini dapat muncul stigma bahwa dosen belum memberikan sentuhan 
inovasi terhadap pola pembelajarannya. Meskipun, tidak semua dosen di perguruan tinggi tertentu berpola seperti demikian. dasarnya adalah masih terdapat beberapa dosen ketika pembelajaran sudah melalui pendekatan IT berupa power point.

Kondisi tersebut seperti yang terjadi dalam proses pembelajaran di Program Studi pendidikan Sejarah IKIP PGRI Madiun. Sepengetahuan penulis proses pembelajaran di Prodi sejarah cenderung menggunakan pendekatan konvensional. asumsinya adalah bahwa secara metode yang digunakan dosen selama perkuliahan berupa ceramah bervariasi. dari sisi penggunaan media bahwa dosen telah memanfaatkan power point sebagai cara untuk menyampaikan materi. materi yang disampaikan hanya berupa tampilan pokok bahasan dari slide yang dibuat. hal ini akan berakibat pada pembelajaran sejarah menjadi membosankan dan tidak menarik (Nur Ahyani, 2013: 13).

Argumentasi ini muncul berdasarkan pengamatan yang dilakukan bahwa beberapa mahasiswa saat mengikuti model perkuliahan masih ada yang kurang fokus terhadap kegiatan pembelajaran. Perihal tersebut juga disinkronkan dengan beberapa informasi dari dosen pengampu mengenai media atau metode yang digunakan dalam kegiatan perkuliahan.

Apabila hal tersebut berlangsung terus-menerus, maka dapat berdampak pada kondisi psikologis dan pemahaman mahasiswa dalam pendalaman materi. selain itu, dapat juga mempengaruhi perfoma dosen terkait dengan capaian pembelajaran yang telah disusun. sebaliknya, bilamana paradigma tersebut secara bertahap bisa dirubah dengan mengembangkan beberapa perangkat pembelajaran, bukan tidak mungkin kegiatan perkuliahan berjalan lebih menarik dan bermakna.

Kondisi ruang kelas sebenarnya mendukung Dosen untuk berinovasi dan memanfaatkannya dalam mengembangkan bahan ajar yang atraktif. hal ini karena dalam kelas tersebut tersedia LCD, proyektor dan seperangkat sound speaker audio. Lebih lanjut, pada hakikatnya pengembangan suatu aspek pembelajaran tidak hanya pada content media, tetapi juga mengandung aspek materi. mengingat bahwa melalui studi eksplorasi sebelumnya perkuliahan yang ada selama ini perihal pemanfaatan sumber belajar di lingkungan sekitar belum dimaksimalkan. Tentu perlu diketahui bahwa lingkungan daerah sekitar mempunyai potensi untuk dimanfaatkan menjadi sumber belajar utamanya ilmu sejarah.

Apabila dicermati, beberapa daerah di Indonesia menyimpan nilai-nilai local wisdom yang cukup banyak. Bentuk potensi kearifan lokal ini adalah beragam peninggalan sejarah. salah satunya adalah Kabupaten Madiun. Kabupaten Madiun merupakan kawasan potensial dengan 
kronik sejarahnya, baik masa pra sejarah hingga masa kemerdekaan.

Apabila digali lebih mendalam bahwa masih terdapat banyak aktifitas lain pada masa itu yang memainkan peran penting dalam peristiwa sejarah Indonesia, dibuktikan dari banyaknya manusia di wilayah Madiun khususnya mengenai bangunan bersejarah. cagar budaya merupakan salah satu bentuk peninggalan bersejarah dan menjadi bukti historis masa lampau madiun yang perlu diketahui atau dipublikasikan. Beberapa potensi cagar budaya kabupaten madiun, secara substansi dapat dimanfaatkan menjadi bahan materi dalam media pembelajaran sejarah di perguruan tinggi. Bilamana merujuk pada Peraturan Menteri Pendidikan Nasional nomor 22 tahun 2006, terkait pelajaran sejarah sebenarnya memiliki tujuan yang jelas.

Tujuan tersebut dapat diintisarikan bahwa agar Mahasiswa memiliki kemampuan memahami, mengapresiasi dan sadar terhadap peninggalan sejarah sebagai bukti peradaban bangsa Indonesia di masa lampau, sehingga rasa bangga dan cinta tanah air dapat diimplimentasikan dalam berbagai bidang kehidupan baik nasional maupun internasional. Orientasinya adalah lebih pada usaha akulturasi nilai budaya. hasil akulturasi budaya dapat membentuk identitas seseorang. Identitas merupakan ungkapan nilai budaya bangsa yang bersifat khas dan membedakan dengan bangsa lain (Dian Din Satuti Mulia, 2014 : 21).

Sikap pembentukan identitas begitu penting dan diperlukan saat ini guna memupuk kebanggaan seseorang. Tentu kebanggaan secara komunal terhadap keunikan atau karakter yang dimiliki setiap daerah, tak terkecuali Madiun. Hal ini diperuntukkan sebagai wujud proses pelestarian budaya masa lampau.

Oleh karena itu, untuk dapat mengaktualisasikan cagar budaya kepada mahasiswa, maka perlu dilakukan pengembangan media yang bertitikan pada pembelajaran kontekstual. pengembangan yang dilakukan adalah dengan kemasan media Visualisasi Cagar Budaya di Madiun. Video cagar Budaya menjadi alternatif media pembelajaran kontekstual. Video tersebut merupakan visualisasi hasil cagar budaya peninggalan masa lampau sekitar Madiun.

\section{Media Pembelajaran Video}

Media pembelajaran dapat dikatakan mempunyai peran penting bagi pendidik guna mempermudah mengkomunikasikan materi saat proses pembelajaran di kelas. Sifat dari media adalah sebagai alat bantu untuk pelaksanaan pembelajaran, serta dapat mengefektifkan dalam upaya penyampaian materi yang diajarkan. Orientasi ini mengacu pada paradigma bahwa penggunaan media bisa menjadi perantara memaksimalkan komunikasi berkenaan 
dengan pesan pelajaran yang akan disampaikan ke peserta didik.

Analoginya adalah media merupakan penyambung relasi komunikasi pendidik dengan peserta didik. Makna media pembelajaran cukup beragam. Kata media merupakan bentuk jamak dari medium. Menurut Sri Anitah (2011: 2) media pembelajaran ialah setiap orang, bahan, alat, atau peristiwa yang dapat menciptakan kondisi yang memungkinkan pembelajar dalam menerima pengetahuan, keterampilan, maupun sikap.

Konsep ini dapat dijabarkan bahwa media pembelajaran itu memiliki ruang lingkup yang cukup luas. Media bisa juga berupa buku, diktat atau bahkan sampai pemanfatan objek dilingkungan sekitar juga dapat dimasukkan ke dalam asumsi media pembelajaran. Hal ini beralasan bahwa segala hal yang sekiranya diprediksikan akan mendukung dan dapat dimanfaatkan untuk keberhasilan pembelajaran dapat dipertimbangkan menjadi sumber/media belajar.

Pada dasarnya sebuah media dapat dikatakan pula sebagai sarana untuk meraih suatu tujuan pembelajaran tertentu. Tujuan tersebut apabila dispesifikkan bahwa adanya ketercapaian keberhasilan pemahaman siswa dalam mencapai kompentensi dari indikator yang telah ditetapkan oleh pendidik. Hal tersebut disebabkan bahwa media memang menuntut content berupa informasi yang dapat dikomunikasikan kepada orang lain (peserta didik). Informasi ini diperoleh dari beberapa buku, rekaman, internet, dan lainnya.

Selanjutnya, pendapat yang lain dikemukakan oleh Criticos (dalam Daryanto, 2011: 4) bahwa media merupakan salah satu komponen dalam berkomunikasi, yakni sebagai pembawa pesan dari komunikator menuju komunikan. Maksud dari pendapat tersebut adalah media dianggap sebagai alat pembawa komunikasi dan di dalam komunikasi tersebut terdapat pesan yang positif untuk memberikan wawasan bagi penerima informasi. Sebagaimana pengertian tersebut, pendidik berposisi sebagai komunikator yaitu sebagai orang yang memiliki pengetahuan dan sebaliknya, siswa bersandar sebagai komunikan yaitu penerima informasi.

Dari Pengkajian berbagai pengertian tersebut, dapat disimpulkan bahwa media pembelajaran merupakan bahan, alat atau perantara yang digunakan pendidik untuk penyaluran pesan yang dirancang untuk kepentingan pendidikan baik secara verbal maupun nonverbal, dalam hal ini berupa isi materi pelajaran kepada peserta didik pada saat proses pembelajaran sedang berlangsung. Tujuannya adalah untuk merangsang serta mendorong pikiran dan kemauan peserta didik dalam memahami berbagai informasi yang tidak mungkin disampaikan secara langsung oleh pendidik. 
berkenaan dengan hal tersebut, pemilihan media merupakan hal yang penting bagi seorang pendidik. ketepatan dalam menggunakan media dapat menjadikan proses pembelajaran bermakna. oleh karena itu, bilamana pendidik belum menemukan media yang sesuai maka seharusnya diupayakan sebisamungkin untuk berkreativitas dalam mengembangkan sebuah media. jenis criteria media yang dapat dikembangkan cukup beragam meliputi konsep visual, audio, audio-visual, dan lain-lain. salah satu bentuk media yang dapat dikembangkan adalah video.

Menurut Niam Wahzudik (2010) menerangkan bahwa media video dapat digunakan untuk menerangkan programprogram formal yang sistematis dan dipakai sebagai bagian integral dari suatu pelajaran sekolah atau lembaga-lembaga pendidikan lainnya. Pada dasarnya media video merupakan kombinasi antara media yang dapat didengar dan dilihat. Media tersebut menggabungkan antara gambar rekaman yang ditayangkan, kemudian diselingi pula berbagai unsur suara yang mendukung unsur gambar. Suara yang ada pada media difungsikan untuk penambah kemenarikan tampilan dengan memadukan ke beberapa penyesuaian scene yang dibuat. Meskipun gambar tersebut hanya diam namun tetap menimbulkan kesan menarik sehingga dapat merangsang naluri untuk tetap menikmati produk tampilan. Media ini dapat dikatakan akan menghasilkan suatu bentuk media sesuai dengan obyek aslinya. Keaslian obyek di sini bisa jadi hasil rekaman benda-benda yang memiliki makna, misalnya candi, monumen, maupun situs-situs (dalam tema sejarah), atau objek benda lainnya dilingkungan sekitar dengan mempertimbangkan urgensi untuk pengembangan bahan media dan dijelaskan ketika pembelajaran.

Kesesuaian obyek yang ditampilkan membuat isi lebih dapat tersampaikan, dan memberi keleluasaan pemaknaan materi secara mendalam. Kondisi seperti ini dan sesuai sasaran penelitian yang dituju yakni mata pelajaran sejarah memang membutuhkan kerja keras dalam upaya membangun penciptaan media agar dapat menimbulkan kesan menarik kepada peserta didik.. Di dalam media video umumnya didukung effect dan berbagai background tampilan serta komponen pendukungnya.

Sejalan dengan ini, penyajian media video banyak dikemas dalam bentuk VCD/DVD, kepraktisan menjadi salah satu daya tarik piranti ini, karena di dalam proses perekaman gambar, proses editing sampai dengan pemanfaatannya lebih praktis jika dibanding dengan teknologi sebelumnya, sehingga berkaitan dengan adanya kemudahan-kemudahan teknik pengoperasian maka sangat dimungkinkan untuk dapat memproduksi secara personal untuk berbagai keperluan termasuk dalam 
bidang pembelajaran (Panitia Sertifikasi Guru Rayon XII Unnes, 2008: 5-37).

Dari berbagai pendapat yang dikemukakan tersebut, dapat disimpulkan bahwa pemaknaan media video lebih diartikan sebagai media pengembangan hasil dari perpaduan teknologi industri yang mengkombinasikan antara gambar dan suara dalam penyampaian materi serta simbol-simbol yang akan disampaikan, sehingga dengan memanfaatkan aplikasi tertentu dan cenderung mengutamakan segi pandangan disertai pendengaran, maka melalui adanya rekaman obyek aslinya akan dapat merangsang peningkatan kinerja pemahaman akan suatu materi yang disajikan dan hasil akhir biasanya dikemas dalam bentuk VCD/DVD.

Ada beberapa jenis video yang dapat digunakan sebagai aplikasi multimedia dapat dimanfaatkan untuk mengkonsep sebuah media pembelajaran yang menarik. Apabila jenis video sesuai dengan desain yang menurut penilaian orang menarik dan sinkron dengan perkembangan zaman, bukan tidak mungkin dapat menimbulkan minat untuk menontonnya. Adapun jenis video tersebut adalah live video feeds,Videotape, Video Disc, Digital Video, Hyper Video (Munir, 2012: 290-291). Dari berbagai macam jenis video yang telah diterangkan diatas, maka dalam pengembangan video ini akan menggunakan jenis digital video. Alasannya adalah video yang dibuat akan disimpan ke dalam kepingan DVD untuk memudahkan guru dan siswa dalam pemakaiannya. Di sisi lain, kualitas film yang lebih baik menjadi faktor penting dalam pemilihan jenis video dan diharapkan nantinya pemilihan ini dapat meningkatkan kualitas penyajian video dalam pembelajaran yang dilakukan.

Adapun Proses pembuatan video ini dapat dilakukan dengan berbagai cara. Namun terdapat beberapa hal penting dalam pembuatan video yaitu penulisan script, perekaman, penyuntingan dan revisi. Video yang diproduksi bisa digunakan untuk berbagai tujuan, sehingga dengan demikian kemampuan unik video adalah untuk menangkap sebuah gambar dan suara dan dapat diputar kembali.

Proses pembuatan media video pembelajaran ini hal yang utama dan penting adalah pembuatan naskah. Naskah sangat berperan dalam proses pembuatan video, sebab dapat menjadi panduan dalam pembuatan video pembelajaran, selain didukung dari sumber daya manusia serta alat yang memadai dapat menentukan kualitas video. Di samping itu dukungan dari berbagai pihak juga dapat menentukan keberhasilan proses pembuatan video pembelajaran. Hal ini dengan adanya bantuan dari berbagai pihak tentu akan mendapatkan beberapa masukan yang gunanya dapat menjadi bahan dalam menyempurnakan media pembelajaran berbasis video, sehingga diharapkan 
menghasilkan kualitas video yang baik, menarik dan interaktif.

Perlu dicermati pula, di dalam penerapan pada saat pembelajaran, pilihan media video ini paling tidak akan memberikan sedikitnya 20 hasil potensial ke siswa selama proses pembelajaran berlangsung. Kedua puluh hasil yang dapat dimanfaatkan dari keuntungan menggunakan media video tersebut antara lain: a). Mengambil perhatian siswa, b). Membuat fokus dan konsentrasi siswa, c). Membangkitkan minat dalam di kelas, d). Menciptakan perasaan bersantai atau energi siswa untuk proses latihan belajar, e). memberikan pada imajinasi siswa, f). Meningkatkan sikap dan reaksi siswa terhadap antusiasme dalam mempelajari isi materi dan pembelajaran, g). Dapat membangun koneksi baik dengan siswa lain dan tutor, h). Meningkatkan ketajaman memori siswa pada materi pembelajaran, i). Meningkatkan pemahaman,

j). Meningkatkan kreativitas, k). Merangsang munculnya ide, l). Mendorong pembelajaran yang lebih mendalam (bermakna), m). Memberikan kesempatan bagi siswa untuk menciptakan kebebasan berekspresi, n). Berfungsi sebagai kendaraan dalam kolaborasi antara guru dan siswa sebagai model pembelajaran langsung, o). Menginspirasi dan memotivasi siswa, p). Membuat belajar menyenangkan, q). Dapat mengatur suasana hati siswa untuk belajar menyenangkan dan terfokus, r). Membantu mengurangi kecemasan siswa dalam kesulitan belajar, s). Meminimalkan ketegangan siswa pada topik pembelajaran menakutkan, t). Dapat membuat gambar visual yang mengesankan

\section{Kajian Pustaka}

\section{Definisi Benda Cagar Budaya}

Pada dasarnya benda cagar budaya bisa disebut juga sumber daya budaya. Seorang arkeolog Edi Sedyawati menelaah kajian tentang munculnya istilah "sumber daya" itu sendiri mengacu kepada suatu penggunaan, atau pemanfaatan tertentu dari sesuatu untuk pencapaian tujuan yang dapat diukur dari segi produktivitas. Jika kata itu disertai dengan keterangan sifat "budaya", maka artinya adalah bahwa yang digunakan atau dimanfaatkan itu adalah hal-hal yang bersifat budaya atau lebih tepatnya hasil-hasil dari suatu kebudayaan (2007: 169).

Artikulasi kebudayaan ini pada dasarnya adalah suatu karya atau buah budi dari sekelompok manusia, dan hasil karya tersebut sekaligus merupakan sistem nilai yang dihayati oleh kelompok manusia besangkutan (I Wayan Sudarma dalam Jnana Budaya, 18 (2), 2013: 225). Saduran tersebut dapat dimaknai sebagai sebuah nilai, hasil budaya yang dicetuskan dan dibuat baik oleh perorangan atau secara kelompok akan mengandung unsur simbolisasi komunal masyarakat 
tertentu dalam segala perilaku dan aktivitas kehidupannya.

Adanya simbol-simbol ini bisa dimaknai menjadi dua, dalam artian pertama sebagai ungkapan dari dalam diri sesorang untuk penghormatan kepada orang yang berjasa (memberikan penghidupan) atau dogmatis dan kedua sebagai alat untuk membantu keberlangsungan aktivitas perjalanan hidup sehari-hari. Perlakuan tersebut oleh kelompok yang bersangkutan, terus dilakukan dan lama kelamaan menjadi nilai yang berharga, sehingga muncul rasa penghayatan luar biasa pada individu (komunal) tersebut. Berpijak pada pemikiran ini pula, tentu hasil kebudayaan perlu ada sebuah perencanaan yang terukur baik dari segi kegunaan, pengelolaan dan pemanfaatan untuk dijadikan suatu pengembangan dalam masyarakat secara luas, tak terkecuali untuk bidangbidang pendidikan.

Selanjutnya, benda cagar budaya diperjelas bahwa bangunan cagar budaya merupakan bangunan buatan manusia berupa kesatuan atau kelompok, atau bagian-bagiannya atau sisa-sisanya yang berumur sekurangkurangnya 50 tahun, atau mewakili masa gaya yang khas dan mewakili masa gaya sekurang-kurangnya 50 tahun, serta dianggap mempunyai nilai penting bagi sejarah, ilmu pengetahuan dan kebudayaan (Peraturan Walikota Surabaya Nomor 59 Tahun 2007). Di tambah lagi memang sisa-sisa bangunan tersebut juga telah menyimpan memori kolektif masyarakat sekalipun wujud ingatan itu masih samar-samar.

Dari beberapa pendapat di atas, maka konsep cagar budaya dapat disederhanakan yaitu bangunan dari hasil karya manusia, minimal telah mempunyai masa kurang lebih 50 (lima puluh tahun) yang terdapat di wilayah tertentu, dan diupayakan untuk tetap dilestarikan maupun dikembangkan sebagai wujud penghormatan kepada budaya masa lampau yang memiliki nilai luhur dan mempunyai hubungan dengan kebudayaan dalam perkembangan manusia masa lalu, serta makna penting bagi sejarah meskipun masih menyimpan memori bagi masyarakat sekitar sehingga dengan demikian dapat difungsikan untuk keperluan ilmu pengetahuan di era modern saat ini. Wujud pemanfaatan dalam studi ilmu pengetahuan khususnya di bidang pendidikan paling tidak inspirasi ketika dibutuhkan untuk membuat sumber belajar.

\section{Jenis Benda Cagar Budaya}

Terkait dengan karakteristik dari pengertian cagar budaya, maka akan terkategorisasi dengan mengacu pada jenis-jenisnya. Di lihat dari konteks 
jenis, maka benda cagar budaya terbagi atas dua kategori, yaitu:

1) Benda buatan manusia, bergerak atau tidak bergerak berupa kesatuan kelompok, atau bagian-bagianya atau sisa-sisanya yang berumur sekurang-kurangnya lima puluh tahun dengan memiliki nilai penting bagi sejarah, ilmu pengetahuan, dan kebudayaan.

2) Benda alam yang dianggap mempunyai nilai penting bagi sejarah, ilmu pengetahuan, dan kebudayaan.

Dari pengkategorian di atas, kemudian mengalami perluasan lagi terhadap penjabaran ini agar dapat menggali dan mendapat informasi tentang benda cagar budaya, maka sesuai yang dipaparkan oleh Uka Tjandrasasmita (dalam Renol Hasan, 2012: 35-36) menerangkan bahwa jenis benda cagar budaya adalah:

1) Benda begerak atau tidak bergerak yang dibuat oleh manusia atau yang merupakan bagian alam. Di dalam kategori ini adalah kelompok benda dan sisa-sisanya yang pokoknya berumur 50 tahun atau memiliki langgam yang khas dan dapat mewakili langgam sekurangkurangnya 50 (lima puluh) tahun serta dianggap mempunyai nilai bagi sejarah, arkeologi dan seni rupa. Termasuk runtuhan bangunan serta benda-benda peninggalannya seperti tembikar, keramik dan lainlain (Been Rafanany, 2013: 102).

2) Benda yang dianggap mempunyai nilai penting bagi paleontropologi.

3) Situs (tapak) yang mempunyai arti penting bagi sejarah dan diduga mengandung benda-benda seperti termuat dalam ayat a dan b.

4) Tanaman atau bangunan yang terdapat diatas situs tersebut dan memiliki atau dapat memiliki kepentingan langsung bagi bendabenda yang termuat dalam ayat a dan b. Apabila keberadaannya di air sebagai suatu misal, bisa diketahui dari temuan-temuan seperti patirtaan, blumbang-blumbang yang disucikan yang dipandang mengalirkan amerta atau air suci (Tjahjono Widarmanto, 2013: 12).

Berdasarkan pengertian di atas maka, dapat disimpulkan bahwa jenis benda cagar budaya secara global dapat dikategorikan sebagai berikut Pertama, benda bergerak yakni, benda yang dapat dipindah misalnya relief atau artefak yang memiliki nilai pengetahuan, kebudayaan, dan kesejarahan dalam perkembangan ilmu tanpa mengurangi substansi dari benda tersebut, Kedua, benda tidak bergerak seperti bangunan kuno, benteng, atau peninggalan sejarah lain yang tidak dapat dipindahkan, Ketiga, situs yang merupakan kesatuan dari lingkungan benda cagar 
budaya tidak bergerak sehingga perlu pelestarian lebih lanjut, Keempat, lingkungan cagar budaya itu sendiri, benda alam, dan wilayah keberadaan cagar budaya.

Pada dasarnya lingkungan biasanya menyertai dari situs yang meliputi bagian dari lahan di yang dalamnya dianggap atau diperkirakan mengandung benda-benda cagar budaya, dan Kelima benda buatan manusia dan/atau alam, berupa kesatuan atau kelompok, atau bagian dan sisanya, situs, serta kawasan yang memiliki nilai urgensi bagi perkembangan ilmu pengetahuan, pendidikan, sejarah, budaya, agama yang telah dan/atau masih dirawat sampai saat ini.

\section{Fungsi Benda Cagar Budaya}

Hakikatnya semua peninggalan sejarah apabila dilihat dari sisi nilai guna pada masa kini, memang dapat difungsikan untuk memberikan pengetahuan dan pemahaman sejarah masa lampau dalam konteks kekinian. Benda cagar budaya misalnya merupakan salah satu hasil karya manusia masa lampau. Secara periodisasi, benda masa lampau dari masa pra sejarah, masa klasik, masa kolonial sampai masa kemerdekaan dapat diambil nilai fungsinya sebagai bahan kajian dalam sejarah suatu bangsa. Bukan hanya itu saja, benda cagar budaya juga dapat dimanfaatkan pada bidang tertentu terutama dalam konteks pendidikan dengan tujuan untuk mengakulturasi rasa cinta peserta didik pada peninggalan warisan budaya yang dimiliki bangsa Indonesia.

Hal ini sesuai pernyataan I Gde Widja (1989: 60) yang menjelaskan bahwa benda cagar budaya yang tersedia saat ini dapat dimanfaatkan sebagai media pengajaran dan alat bantu untuk mendukung usaha-usaha pelaksanaan strategi serta penerapan metode mengajar. Apabila dicermati lagi, berlandaskan dari keberadaan peninggalan sejarah khususnya di lingkungan sekitar, maka benda-benda tersebut bisa dijadikan sebuah alternatif untuk pemanfaatan sumber belajar sekarang ini. Meskipun Peninggalan purbakala ini mudah rusak karena alam dan faktor usia (Radar Ponorogo, 2014: 31). Kerusakan ini disebabkan oleh faktor alam misalnya gempa bumi, banjir, gunung meletus dan kerusakan oleh faktor kimia seperti adanya pengaruh oksidasi serta kerusakan yang disebabkan oleh faktor bioligik yaitu disebabkan oleh perlakuan benda-benda hidup seperti tanaman, binatang dan manusia (Masyudio, 2012: 167). Namun demikian, sisa-sisa tersebut masih terbentuk sesuai kondisi aslinya dan bisa dikemas untuk pengembangan materi ajar. Pengangkatan tema benda cagar budaya, perlu diintegrasikan dengan cara mengkreasikan dalam bentuk media yang menarik. Hasil media tersebut tentu untuk proses pembelajaran peserta didik agar lebih efektif. Di sisi lain, peninggalan masa lalu yang mempunyai nilai guna ilmu 
pengetahuan dapat teralkulturasi kepada peserta didik. Harapannya adalah dapat menginventariskan nilai-nilai karakter peserta didik berupa penanaman kecintaan terhadap warisan budaya sejarah bangsanya sendiri.

Selain itu, Uka Tjandrasasmita (dalam Renol Hasan, 2012: 40) menerangkan fungsi cagar budaya adalah Pertama, sebagai bukti-bukti sejarah dan budaya yang dapat menjadi alat atau media yang mencerminkan cipta, rasa dan karya leluhur bangsa, yang kepribadiannya dapat dijadikan suri tauladan bangsa, kini dan mendatang dalam rangka pembinaan dan mengembangkan kebudayaan nasional belandaskan pancasila, Kedua, alat atau media yang memberian inspirasi, aspirasi, dan akselerasi dalam pembangunan bangsa baik material maupun spiritual, sehingga tercapai keharmoniasan diantara keduanya,

Ketiga, obyek ilmu pengetahuan dibidang sejarah dan kepurbakalaan pada khususnya dan ilmu pengetahuan lain pada umunya, Keempat, alat pendidikan visual kesejarahan dan kepurbakalaan serta kebudayaan bagi peserta didik untuk memahami budaya bangsa sepanjang masa, Kelima, alat atau media untuk memupuk saling pengertian di kalangan masyaakat dan bangsa serta umat manusia melalui nilai-nilai sosial budaya yang terkandung dalam peninggalan sejarah dan purbakala sebagai warisan budaya dari masa lampau, Keenam, sebagai media untuk memupuk kepribadian bangsa di bidang kebudayaan dan ketahanan nasional, dan Ketujuh sebagai obyek wisata yang mungkin dapat menambah pendapatan masyarakat daerah sekitarnya.

Keputusan untuk menampilkan pengenalan pada cagar budaya melalui kandungan nilai historisnya, maka peserta didik dengan mudah dalam memahani serta dapat memberikan makna dalam pembelajaran. Di samping itu, mendorong kesadaran sejarah melalui cerita atau kronik peristiwa sejarah dari keberadaan benda cagar budaya yang memang cukup penting sehingga, pemahaman akan perjuangan dalam hal kebangsaan bisa teraktualisasi.

\section{Metode Penelitian}

Model penelitian ini adalah Research and Development (R\&D), dengan menggunakan langkah-langkah dari Borg and Gall. Sugiyono (2013: 297) mengatakan bahwa metode pengembangan merupakan model penelitian yang digunakan untuk menghasilkan produk tertentu, dan menguji keefektifan produk yang dihasilkan. Pada dasarnya penelitian ini berdasarkan analisis kebutuhan dan menguji keefektivitasannya agar dapat berfungsi sesuai nilai kebermanfaatanya. Selanjutnya, metode yang digunakan dalam penelitian ini adalah deskriptif, evaluatif, dan eksperimental (I Gde Rasagama, 2011: 4). Tahap deskriptif digunakan untuk mengungkap dan menjelaskan temuan awal penelitan di lapangan, berupa kondisi pembelajaran 
serta cagar budaya kabupaten Madiun. Metode evaluatif digunakan untuk mengevaluasi produk pengembangan dengan uji coba. Metode eksperimen digunakan untuk mengukur keampuhan produk pengembangan. Di dalam penelitian ini merupakan model pengembangan Borg \& Gall termodifikasi dan langkahlangkahnya terbatas hingga langkah ke tujuh.

\section{Studi Pendahuluan}

Langkah pertama yang dilakukan adalah pengumpulan informasi awal melalui analisis kebutuhan. Analisis kebutuhan dilakukan dengan wawancara ke beberapa dosen dan mahasiswa Program Studi Pendidikan Sejarah IKIP PGRI Madiun. Selain itu, studi pustaka dilakukan dengan tujuan menghimpun landasan teoritik sebagai bahan untuk dasar pengembangan media.

Selanjutnya, studi lapangan juga diperlukan untuk menganalisa konsep pengembangan yang akan diterapkan. Studi lapangan akan didapatkan deskripsi keadaan obyek yang dijadikan sampel penelitian dengan proses pengamatan. Proses ini akan memperoleh informasi mengenai media yang pernah dilakukan oleh Dosen terkait pemanfaatan sumber belajar lingkungan sekitar dan sekaligus merencanakan materi sebagai bahan pengembangan.

\section{Tahap Pengembangan Model}

a. Desain produk

Tahap awal desain produk, yang pertama dilakukan adalah mengumpulkan data-data tentang Potensi cagar budaya Kabupaten Madiun. Data berupa informasi dari kajian hasil pustaka dan wawancara ke informan di lapangan penelitian. Selanjutnya, menghimpun serta memetakan bentuk peninggalan cagar budaya Kabupaten Madiun. Setelah data terkumpul, kemudian disusun menggunakan software Movie Makker versi 2.6, sehingga akan menghasilkan video. Pada hakikatnya isi video ialah dengan mengimport hasil shooting cagar budaya, sekaligus memberi narasi teksnya. Skema dibawah ini, dapat memperjelas desain yang direncanakan:

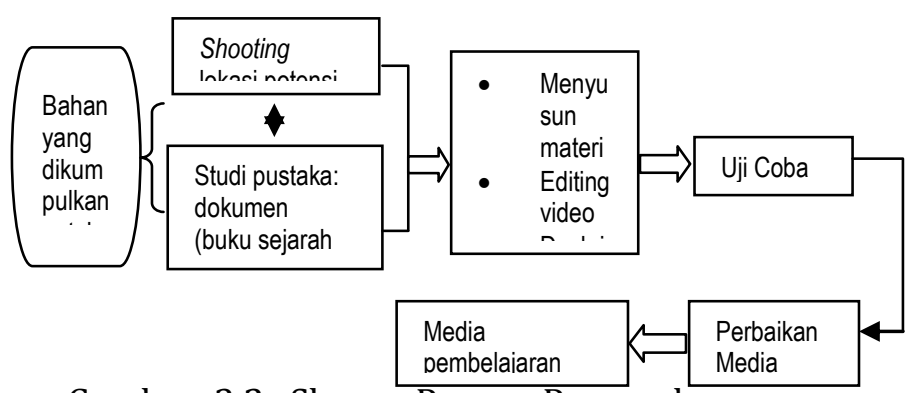

Gambar 3.2. Skema Proses Pengembangan Produk Video

a. Validasi Desain Produk

Validasi desain ini bermaksud untuk mengetahui sejauhmana media yang dikembangkan dalam penelitan ini telah siap uji coba di lapangan. Pemilihan ahli ditunjuk berdasarkan kemampuan dalam bidang keilmuannya. 
Adapun ahli yang dibutuhkan yaitu ahli media dan saran materi serta dari rekan sejawat. Di dalam hal ini Validator ahli media adalah Dr. Muhammad Hanif, M.M., M.Pd, saran materi adalah Drs. Abraham Nurcahyo, M.Hum, Hery Priswanto, S.S. dan Dra. T.M. Rita Istari (Peneliti Balai Arkeologi Yogyakarta) dan beberapa rekan dosen.

b. Revisi Desain

Revisi desain dan penyempurnaan produk dilaksanakan sesuai dengan masukan dan saran dari ahli media, ahli materi maupun rekan dosen.

c. Ujicoba Produk

Dari produk video pembelajaran dengan materi peninggalan sejarah di daerah masing-masing sehingga produk layak dan siap digunakan sebagai alternatif media pembelajaran IPS

e) Teknik Analisis Data

Pada tahap ini peneliti melakukan analisis penilaian untuk dapat membandingkan keberhasilan penerapan media video berbasis benda cagar budaya melalui hasil pre-test dan post-test. Artinya, bagaimana perbandingan siswa sebelum diberi media pengembangan dan sesudah diberi media, namun tanpa menghadirkan kelas kontrol. Teknik uji yang dipakai untuk mendapatkan perbedaan nilai tersebut dengan menggunakan statistik parametrik. Jenis statistiknya adalah uji t menggunakan model non-independent (Paired Sample $t$ Test).

Sehubungan dengan persyaratan statistik itu datanya harus berdistribusi normal dan homogen, lalu untuk menguji normalitas maka menggunakan jenis uji one sample kolmogorov-smirnov dan uji homogenitas memakai oneway anova serta pengolahan data menggunakan bantuan analisis statistik program SPSS versi 16. Berdasarkan maksud uji ini untuk melihat sejauh mana tingkat keberhasilan produk pengembangan terhadap dampak pengiring yang diukur tentang tes prestasi, jadi hipotesis yang diajukan adalah

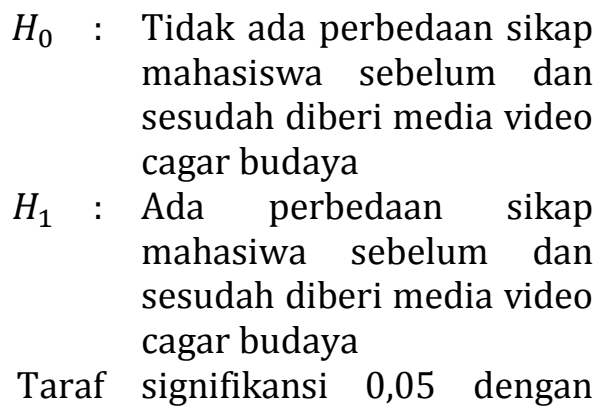
keputusan uji:

$\begin{array}{ll}H_{0} & \begin{array}{l}\text { Diterima jika signifikansinya > } \\ 0,05\end{array} \\ H_{0} & \text { Ditolak jika signifikansinya < } \\ & 0,05\end{array}$

\section{Tahap Evaluasi}

Setelah dilakukan pengujian terhadap produk yang dikembangkan, (dari berbagai tahap uji terbatas sampai uji skala luas), masih dimungkinkan adanya revisi produk (secara keseluruhan). Pada akhirnya diperoleh produk final yaitu media Vicaya untuk 
Mahasiswa IKIP PGRI Madiun. Keberhasilan efektivitas produk ini adalah bilaman terdapat perbedaan hasil antara sebelum (before) dan sesudah (after) ditreatmenkan.

\section{Pembahasan}

Madiun selama ini hanya di kenal sebagai kota transit saja. Kurangnya informasi tentang situs ataupun benda cagar budaya di Madiun menjadikan kota ini sepi untuk kategori pariwisata budaya, padahal potensi Madiun sangat besar. Berdasarkan hal tersebut juga lah peneliti terinspirasi untuk membuat sebuah media pembelajaran sejarah yang bersumber dari cagar budaya yang ada di sekitar Madiun. Beberapa cagar budaya yang ada di Madiun diantaranya, Makam Kuno Taman, Masjid Kuncen, Prasasti Klegen Serut, Prasasti Sendang Kamal, Candi Wonorejo, dan masih banyak yang lain.

Cagar budaya yaitu bangunan dari hasil karya manusia, minimal telah mempunyai masa kurang lebih 50 (lima puluh tahun) yang terdapat di wilayah tertentu, dan diupayakan untuk tetap dilestarikan maupun dikembangkan sebagai wujud penghormatan kepada budaya masa lampau yang memiliki nilai luhur dan mempunyai hubungan dengan kebudayaan dalam perkembangan manusia masa lalu, serta makna penting bagi sejarah meskipun masih menyimpan memori bagi masyarakat sekitar sehingga dengan demikian dapat difungsikan untuk keperluan ilmu pengetahuan di era modern saat ini. Wujud pemanfaatan dalam studi ilmu pengetahuan khususnya di bidang pendidikan paling tidak inspirasi ketika dibutuhkan untuk membuat sumber belajar.

Berdasarkan hasil observasi yang dilakukan pada mahasiswa Program Studi Pendidikan Sejarah IKIP PGRI MADIUN bahwa Paradigma yang berkembang selama ini adalah sejarah itu membosankan dan terlalu banyak ceramah tanpa diimbangi dengan fakta riil nya, sehingga bisa dikatakan sejarah cenderung dianak tirikan.

Adanya media pembelajaran yang menarik diharapkan mampu memberikan paradigma baru pada mahasiswa khususnya mahasiswa Program Studi Pendidikan Sejarah IKIP PGRI MADIUN agar lebih mencintai dan termotifasi belajar sejarah.

Salah satu alternatif media yang telah digunakan adalah Sua Dara yang merupakan singkatan dari Visualisasi Benda Cagar Budaya sebagai alternatif media pembelajaran sejarah. Pada awalnya peneliti melibatkan tiga orang mahasiswa untuk mengunjungi cagar budaya yang ada di sekitar Madiun. Setelah itu mendokumentasikannya dalam kamera dan video, lalu penulis mengedit gambar dan memberi suara atau proses dubbing serta musik agar tampilan video lebih menarik. Jika proses tersebut telah dilakukan maka yang terakhir adalah menyimpan file pada compact disk dan menggandakannya untuk kepentingan pengajaran. 
Hasil yang dicapai adalah, dengan menggunakan media ini dalam menerangkan atau menjelaskan materi di kelas, mahasiswa menjadi lebih antusias dalam mengikuti perkuliahan. Selain itu dapat meningkatkan pola berpikir kritis mahasiswa.

\section{Simpulan}

Proses belajar mengajar yang dilakukan di kelas hendaknya mampu menarik minat peserta didik. Proses belajar mengajar dikatakan berhasil jika peserta didik mampu menyerap segala informasi sesuai materi yang diberikan, selain itu faktor pendidik juga memegang peranan penting dalam keberhasilan pembelajaran di kelas. Pendidik harus mempunyai metode pengajaran serta mampu berkreasi dan berinovasi dalam membuat media pembelajaran sehingga peserta didik dalam hal ini adalah mahasiswa program studi pendidikan Sejarah tidak lagi merasa bosan mempelajari materi yang diberikan oleh pendidik atau dosen. Melalui Sua Dara ini ternyata mampu menarik minat mahasiswa untuk belajar sejarah khususnya sejarah lokal sekitar tempat tinggalnya.

\section{Saran}

1. Diharapkan para pendidik dalam hal ini dosen agar lebih meningkatkan kreativitas dalam membuat media pembelajaran

2. Diharapkan para pendidik dalam hal ini dosen lebih inovatif dalam menggunakan metode pembelajaran sehingga mahasiswa tidak lagi bosan dengan materi yang diajarkan

\section{Daftar Pustaka}

Ahmad Baedowi. 2012. Calak Edu: Esai-Esai Pendidikan 2008-2012 Jilid 1. Jakarta: Pustaka Alvabet.

Anderson, Ronald. H. 1987. Pemilihan Dan Pengembangan Media Video Pembelajaran. Jakarta: Grafindo Pers.

Berk, Ronald A. 2009 Multimedia Teaching With Video Clips: Tv, Movies, Youtube, And Mtvu In The College Classroom. International Journal of Technology In Teaching And Learning, 5 (1), 2009: 121, (Online), www.ronberk.com (diakses 2 Maret 2014, pukul 12.30).

Borg, Walter \& Gall, Meredith Damien. 2007. Educational Research. New York: Longman.

Daryanto. 2011. Media Pembelajaran. Bandung: Satu Nusa.

Deni Darmawan. 2012. Inovasi Pendidikan Pendekatan Praktik Teknologi Multimedia Dan Pembelajaran Online. Bandung: PT Remaja Rosdakarya.

Dian Din Astute Mulia. 2014. Pengembangan Mutual Differentiation Model Melalaui Dongeng Sebagai Strategi Pembentukan Identitas Nasional Menghadapi Tantangan Multikulturalisme Sejak Usia Dini. Call For Papers Lolos Seleksi Kongres Pendidikan, Pengajaran Dan Kebudayaan II. Yogyakarta: 21. (Abstr.).

Dinas Kebudayaan dan Pariwisata Kota Malang. 2012. Laporan Kegiatan Inventarisasi Cagar Budaya Di Kota Malang 2012. Kerjasama Antara Kementrian Pendidikan dan Kebudayaan Direktorat Jenderal Kebudayaan Balai Pelestarian Cagar Budaya Trowulan dan Dinas 
Kebudayaan dan Pariwisata Kota Malang.

Edi Sedyawati. 2007. Budaya Indonesia: Kajian Arkeologi, Seni, dan Sejarah. Jakarta: Pt Rajagrafindo Persada.

Ermawan Susanto. 2010. Media Audio Visual Akuatik Untuk Meningkatkan Kualitas Pembelajaran. Paedagogia: Jurnal Penelitian Pendidikan. Nomor 1 Tahun 13 Februari 2010: 1-21.

I Gde Rasagama. 2011. Memahami Implementasi Educational Research And Development. Makalah disampaikan dalam Kegiatan Pelatihan Metodologi Penelitian Untuk Dosen Unit Pelayanan Mata Kuliah Umum dan Unit Lainnya. Politeknik Negeri Bandung: 16 Agustus 2011.

I Gde Widja. 1986. Strategi Pengajaran Sejarah. Jakarta: Depdikbud.

I Wayan Sudarma. 2013. Fungsi Dan Makna Upacara Dewa Meseraman Di Pura Panti Timrah Desa Paksabali Klungkung Bali. Jnana Budaya: Media Informasi Sejarah, Sosial dan Budaya. Nomor 02 Tahun Volume 18 Agustus 2013: 225-240.

Munir. 2012. Multimedia: Konsep Dan Aplikasi Dalam Pendidikan. Bandung: Penerbit Alfabeta.

Niam Wahzudik. 2010. Naskah Video: Mata Pelajaran Bahasa Jawa Kelas Iv Sd Semester I Pokok Bahasan Mengenal Tokoh-Tokoh Wayang Sub Pokok Mengenal Sifat Raden Arjuna. Kurikulum Dan Teknologi Pendidikan Fakultas Ilmu Pendidikan: Universitas Negeri Semarang.

Nur Ahyani. 2013. Kemampuan Berfikir Kritis Dalam Pembelajaran Sejarah. Makalah disajikan dalam Seminar Nasional Membangun Strategi Pembangunan Di Bidang Pendidikan
Dan Kebudayaan, Universitas Sebelas Maret Surakarta, 7 Mei 2013.

Panitia Sertifikasi Guru Rayon XII. 2008. Pendidikan Dan Latihan Profesi Guru (PLPG) Sertifikasi Guru Dalam Jabatan Tahun 2008: Seni Budaya. Universitas Negeri Semarang.

Peraturan Menteri Pendidikan Nasional Republik Indonesia No. 22 Tahun 2006 Tentang Standar Isi Untuk Satuan Pendidikan Dasar Dan Menengah. 2006. Jakarta.

Peraturan Walikota Surabaya Nomor 59 Tahun 2007 Tentang Pelaksanaan Peraturan Daerah Kota Surabaya No 5 Tahun 2005 Tentang Pelestarian Bangunan Dan/Atau Lingkungan Cagar Budaya. 2007. Surabaya.

Renol Hasan. 2012. Benda Cagar Budaya Kota Gorontalo Sebagai Sumber Belajar Sejarah Kebudayaan Indonesia. Tesis. Surakarta: Program Pascasarjana Universitas Sebelas Maret. (Unpublished).

Smaldino, Sharon E., Lowther, Deborah L., Russell, James D. Instructional Technology And Media For Learning: Teknologi Pembelajaran dan Media Untuk Belajar Ed. 9, Cet. 1. 2008. Terjemahan Oleh Arif Rahman. 2011 Jakarta: Kencana Prenadaa Group.

Sobana Hardjasaputra. 2006. Situs Dan Benda Cagar Budaya Di Purwakarta Serta Upaya Pelestariannya. Makalah disampaikan dalam Seminar Perlindungan Situs Dan Benda Cagar Budaya Dalam Menjunjung Eksistensi Jatidiri Budaya Purwakarta, Tim Ekspedisi Purwacinta Badan Pariwisata Kabupaten Purwakarta, Purwakarta, 21 September 2006.

Soebijantoro. 2011. Peran Pendidikan Sejarah Dalam Pengembangan Pembelajaran Multikultur Di LPTK. 
Agastya. No.1 Tahun 1 Januari 2011: 17-26.

Sri Anitah. 2011. Media Pembelajaran. Surakarta: LPP UNS.

Sugiyono. 2013. Metode Penelitian Pendidikan: Pendekatan Kuantitatif,
Kualitatif, dan R\&D. Bandung: Alfabeta. 